\title{
How (Not) to "Study Up": Points and Pitfalls When Studying International Heritage Regimes
}

\author{
Herdis Hølleland $^{\mathrm{a}^{*}}$ and Elisabeth Niklasson ${ }^{\mathrm{b}}$ \\ ${ }^{a}$ Heritage \& Society, Norwegian Institute for Cultural Heritage Research, Oslo, Norway; \\ ${ }^{b}$ Stanford Archaeology Center, Stanford University, Palo Alto, California.
}

*Herdis Hølleland, Heritage \& Society, Norwegian Institute for Cultural Heritage Research, Storgata 2, 0155 Oslo, Norway. Email: herdis.holleland@gmail.com Orcid: 0000-0002-37703178

Herdis Hølleland (PhD, 2013, University of Oslo) worked as a Senior Researcher at the Norwegian Institute for Cultural Heritage Research (NIKU) and a visiting scholar at Stanford Archaeology Center whilst working on the article. She is currently working for the Norwegian Ministry of Education and is affiliated with the HEI: Heritage Experience Initiative at the University of Oslo. Her research has focused on the implementation of UNESCO's World Heritage Convention and Scandinavian heritage politics and bureaucracies more generally.

Elisabeth Niklasson (PhD, 2016, Stockholm University) is a Postdoctoral Researcher at Stanford Archaeology Center. Her research is focused on how archaeology functions social and political capital in national and international heritage regimes. By approaching funding schemes, governmental proceedings and bureaucratic practices as sites for heritage making - combining ethnography and text analysis - she has explored how European Union institutions influence our understanding of the past. Currently she examines heritage as a factor in political polarization in Europe, with specific emphasis on the role of archaeology in the cultural politics of the Scandinavian far-right. 


\title{
How (Not) to "Study Up": Points and Pitfalls When Studying International Heritage Regimes
}

\begin{abstract}
Archaeological fieldwork is no longer what it used to be. Over the last decades archaeologists have begun to "study up". Approaching regional, national and international heritage regimes, they have empirically scrutinized how institutions and people in positions of influence shape what will count as "our common past" tomorrow. This has paved the way for a deeper and more nuanced understanding of contemporary heritage governance. It has also meant stepping onto a minefield of ethical and methodological challenges that archaeologists are often unprepared for. In this article we address some of the points and pitfalls of investigating international heritage regimes, starting from our own experiences studying UNESCO and the EU and putting them in conversation with the experiences of other scholars studying up. By reflecting on the reasons for studying up, and discussing the hands-on challenges of access, anonymity, and research reception, we aim to promote a stronger and more transparent tradition of studying up in archaeology.
\end{abstract}

Keywords: study up; fieldwork; UNESCO; EU; heritage politics; methods; cultural heritage

\section{Introduction}

The scope of what is considered fieldwork in archaeology has expanded over the last decades. While some have left the excavation trenches for scientific or digital laboratories, others have left the sites themselves for the glossy tables and backrooms where decisions are taken about what will count as heritage tomorrow (e.g. Luke 2016). By embracing different qualitative methods, such as institutional ethnography, interviews and textual analysis, an emerging group of researchers have begun to study $20^{\text {th }}$ and $21^{\text {st }}$ century heritage politics in great detail. In doing so they are bringing the cross-disciplinary tradition of "studying up" (Nader 1972) to archaeology. That is, they are empirically examining how structures, processes, organizations and people in positions of influence shape our societies official understanding- and governance of the past: the "actors that ostensibly 'make' heritage" (Meskell 2018, 20). 
In this paper we reflect on the value of studying up in archaeology, as part of the wider field of heritage studies, and identify some methodological challenges and ethical pitfalls brought on by this new direction. Placing particular focus on international heritage regimes (e.g. Bendix et al. 2012; Bendix 2013; Geismar 2015), we ask: How do you get access to the political and bureaucratic environments where the governing principles of heritage regimes are formed? How do you build trust when studying organizations that have built-in safeguards to protect themselves against critique? What happens when the people you study are not only alive and eager to read your work, but consist of your colleagues or future employers? And, how do you deal with the discovery of sensitive information and unofficial practices without hurting the people or organizations under study?

Our motivation for addressing these questions is twofold. First, we believe that the reasons behind- and the practice of studying up can speak to critical issues archaeology is facing right now, especially concerning the democratic relevance of our work in times of political polarization. Second, in view of debates on the "fragmentation" of archaeology (Lucas 2015; Nilsson Stutz 2018) - dealing with everything from heritage politics to bio archaeology - and concerns about scientific adequacy, we believe that if "studying up" is to make a lasting contribution, it needs to be ethically and methodologically sound. This demands a certain transparency regarding how researchers generate data and arrive at their conclusions, something which is often missing in archaeologists' accounts of studying up, particularly when pursuing ethnography (Pyburn 2009; Zarger and Pluckhahnin 2013). By drawing on anecdotes, reflections and notes from our own research and the emerging literature on international heritage regimes, we hope to increase such transparency.

We arrive at these mutual concerns from two different but complementary perspectives. Hølleland, an archaeologist and heritage researcher turned civil servant, has studied the United Nations Educational, Scientific and Cultural Organization (UNESCO) and 
its 'World heritage regime' from the inside and out - from site level to the international stage (e.g. Hølleland 2013, 2014, 2015; Hølleland and Phelps 2018; Hølleland et al. 2019; Hølleland and Wood 2019). Niklasson, an archaeologist and lecturer in cultural heritage, has studied the European Union (EU) and its burgeoning 'European heritage regime', created at the boundary between archaeology, money and politics in the realm of EU cultural policy (Niklasson 2013, 2016, 2017, 2019). To this end we have both pursued ethnographic observation. Niklasson in a European Commission agency that administers funding for cultural heritage and Hølleland at the World Heritage Committee and in national heritage agencies. This has been combined with interviews with civil servants in national and international bureaucracies, and with independent heritage experts and archaeologists working in various capacities for the organizations. We have also done extensive archival research, tracing the origins and development of heritage policies from idea to implementation.

Starting from these experiences, we approach heritage as a concept, an instrument of governance, and a set of objects and practices that together form a "world-making" device. Our research seeks to understand what makes this device "tick", and how archaeology, as one of the conditions for the possibility of heritage, operates within it. The point of studying up in archaeology, as we see it, is not to produce hollow critique. Neither is it to affect immediate institutional change or to overturn existing heritage policies. Instead, we consider studying up as a means to better understand and identify obstacles to change in the political and organizational contexts where archaeology resides and enables heritage regimes. In producing such accounts, studying up has the potential to impact governing practices and policies in the long term. This potential may in fact be greater in archaeology than elsewhere: Unlike most endeavors in the social and political sciences who study bureaucracies, what makes studying up in archaeology different, is that it does not only seek to understand communities of officials and experts but to understand itself. 
The article consists of two parts. In the first part we begin by discussing how studying up can provide a fruitful addition to current debates in archaeology. We then outline what studying up entails and what characterizes international heritage regimes. Throughout, we draw on our own experiences studying the politics of the past within UNESCO and the EU, as well as reflections and relevant examples provided by other researchers. The second part of the article is structured around three common practical and ethical challenges we have faced, and possible strategies to overcome them.

\section{What Is the Point of Studying Up?}

The term "studying up" was first coined by Laura Nader (1972) as she called on her fellow anthropologists to reinvent anthropology, by exploring the private and public institutions of power in their own societies. Specifically, Nader challenged anthropologists' tendency to choose field situations wherein "power relationships favor the anthropologist" (Nader 1972, 289). Instead of focusing foremost on the colonized or the poor, she suggested, we should study the colonizers and decision makers. For instance, by approaching "the law firm as a secret society" or by describing the "unwritten customary behaviors" that make "Congress tick" (Nader 1972, 293). She argued that the "consequences of not studying up as well as down are serious in terms of developing adequate description and theory" (Nader 1972: 290). Studying up, in other words, is a matter of scientific adequacy, of making sure anthropological accounts are balanced and nuanced.

Another reason to study up raised by Nader is democratic relevance. She points out that for a citizenry to "function in a democracy" and be able to make the "“system" work for them", they need to know how they can exercise their rights in more ways than just voting (Nader 1972, 294). For this they need to understand how things work inside the major institutions that impact their lives. Studying up, she argues, is about linking groups and individuals to larger processes of change. Researchers should therefore write not just for other 
scholars or a native readership - such as communities of officials - but for the citizenry. If informed by close descriptions of bureaucratic cultures, they may be better equipped to affect change (Nader 1972, 295). Seen from this perspective, studying up can be a way of providing public access to decision makers and institutions of governance beyond journalism.

Nader's arguments for scientific adequacy and democratic relevance applies to archaeology in several ways. The discipline's long preoccupation with the powerful of the past and self-awareness vis-à-vis its political nature (e.g. Childe 1933; Clarke 1973) already offer ample justification for examining contemporary networks of influence, but there are areas where studying up can be particularly valuable.

In research which examines archaeology as a modern heritage in its own right, looking at its social and political history, studying up can increase scientific adequacy by securing a temporal balance. Here, focus has long been directed upwards, to the role of archaeology in $19-20^{\text {th }}$ century nation building, colonialism and imperialism, and to historically influential archaeologists and their various political entanglements (e.g. Trigger 1984, 1989; Kohl and Fawcett 1995; Díaz-Andreu and Campion 1996; Kohl 1998; Díaz-Andreu Garcia 2007). While many have linked these legacies to their repercussions in present-day heritage regimes (e.g. Hamilakis and Duke 2007; Berg 2016), especially in the direction called "anthropology of archaeology" (Castañeda 2008) which often employs ethnography (Hamilakis 2011), the people who create and uphold current heritage regimes tend to escape scrutiny. By including them we can catch archaeology's legacies still at work. For instance, when observing written and real-world interactions between archaeologists and EU officials in the EU grant domain, Niklasson saw how cultural historical ideas of Europe as a unique civilization were revived as a justification for EU cultural policy (Niklasson 2016, 2017).

Achieving this temporal balance also feeds into the question of democratic relevance. Today, nationalist, authoritarian and nativist political groups increasingly draw on heritage to 
support visions of cultural continuity (e.g. Bonacchi et al. 2018; Gardner 2018; Niklasson and Hølleland 2018). Recent exchanges between archaeology, news media and politics in studies on ancient migration (Hakenbeck 2019; Gannon 2019), have also made it clear that the concepts of culture and race were never successfully disentangled within the discipline. Society's expectations on archaeology to reinforce political identities persist, and the work of decolonizing the field is far from finished (Hamilakis 2018a; Thomas 2018). To face these challenges, many archaeologists have studied "sideways", by doing ethnographies of archaeological field projects (Edgeworth 2006), or by incorporating ethnography as a strategy to "substantiate an ethics of responsibility" towards descendant communities and publics invested in archaeological pasts (Castañeda 2008, 40). Others have suggested we develop a "new public archaeology" that confronts reactionary populist groups and proactively opposes exclusionary uses of the past (González-Ruibal et al. 2018). Alongside such action, studying up can offer a more anticipatory approach to the politics of the past, and aid long-term disciplinary and sector-wide self-reflection. The democratic relevance, thus, borrowing the words of Tim Murray (in Babic' et al. 2017, 22), would be to "protect society from archaeology" by exposing the assumptions that enable ethnic essentialism, and to work to instill new expectations and relevancies for archaeology in future heritage regimes.

A second area where studying up in archaeology can help increase scientific adequacy is in (critical) heritage studies, where focus is more broadly set on the values, meanings and uses of the past in present societies. So far, most studies in this area have directed the empirical gaze "down". Driven by a sense of indignation over the Western hegemony and rule of experts (e.g. Byrne 1991; Smith 2004, 2006), researchers have demonstrated how "nonexpert communities" - be they indigenous, working class, or metal detecting groups - often have different ideas about what is worth preserving than the "experts" who have traditionally defined what counts as heritage (e.g. Smith and Waterton 2010; Smith et al. 2011; Ferguson 
2016; Jones 2017; Hamilakis 2018b). In tandem with new collaborative and "open” approaches to archaeology (Milek 2018), these studies have successfully nuanced and complicated simplistic images of "the public", revealing a myriad of ways in which individuals and local groups may resist expert rule (e.g. Mortensen and Hollowell 2009; Schofield 2014). As such they have made an excellent case for studying up. To fully grasp the democratic deficits inherent in different heritage regimes, we have to know the recent historical contexts they grew out of and how they work on a daily basis. Here archaeology is an important focus since it has been pinpointed as one of the most conservative elements (Smith and Waterton 2009). But while political institutions and international organizations provide a vital backdrop in such studies, the people that inhabit them rarely escape the stereotypes of the "elite" or "establishment", presented as driven by the goal of perpetuating “Authorized Heritage Discourse(s)" (Smith 2006).

By treating officials, civil servants and experts with the same amount of empirical attention and analytical sensitivity as other communities, studying up can enhance scientific adequacy by complicating the image of the expert and challenge assumptions of who holds power over heritage. When Niklasson (2016) traced the hands and settings that archaeological project proposals passed through in search for EU funding, she found that alongside EU officials and expert reviewers, who often worked under unforgiving circumstances, some of the most influential actors were external consultants, paid to design EU proposals for clients in cultural heritage. Findings from the growing body of research on the World Heritage regime also illustrates this well: Case studies of site nominations and "In Danger" listings, combined with historic-statistical analyses and ethnographies of decision-making in the World Heritage Committee, have revealed how national political concerns, diplomacy and economic ties often hold more sway than bureaucratic procedures and expert assessments (e.g. Meskell 2012a, 2015, 2016, 2018; Brumann 2014a, 2017; Bertacchini et al. 2016; Brown 
et al. 2019; Hølleland and Wood 2019). Researchers have also highlighted how the holy grail of socio-economic development is changing the values of heritage beyond UNESCO (Silberman 2014), and how institutions like the World Bank are defining archaeological heritage management globally (Samuels 2016, 2019). By cultivating such a dual gaze, studying up can contribute to more balanced descriptions of what makes contemporary heritage regimes "tick". Such accounts, in turn, can raise democratic relevance by provoking institutional self-reflection and by informing citizens who seek to influence heritage processes.

Lastly, it is worthwhile to reflect on what archaeologists may contribute to the wider tradition of studying up. Starting from the situated perspective of archaeology when approaching settings in which, as Luke $(2016,641)$ puts it, "official and unofficial conversations often deploy archaeological evidence as part of their rhetoric, evidence that in turn may structure the future of heritage policies", can allow for greater sensitivity regarding the socio-political legacies of different heritage domains. When analyzing the EU's new European Heritage Label, Niklasson (2019) found that scholars from other fields analytically bunched sites such as the Athens Acropolis in Greece and the Gdańsk Shipyard in Poland together, thereby mirroring the political aim behind the initiative. In reality, such sites perform very different types of heritage-work, making different "Europes" possible. Through an awareness of archaeology's role in national identity building, pivoting between science and myth, the different political roles played by ancient sites versus more recent ones became visible. In their research on archaeology as cultural diplomacy in US foreign policy, Luke and Kersel $(2013,11-14)$ also argue that archaeologists are ideally suited to turn the mirror to themselves, since their work tends to embody the smart power strategies of contemporary regimes, always moving "between the upper echelons of government and local communities". Focusing more on time depth, Meskell $(2016,20)$ makes the point that her archaeological 
training has led her to focus on "long-term patterns and evidence of change", and that it is through this perspective she has been able to see that "[f]rom the archives to my interviews to the international gatherings, all roads led back to politics." What makes her approach different, she argues, is the foregrounding of the past's materiality and the attempts to control its afterlife. She conceptualizes her "archaeological ethnography" as a methodologically hybrid practice at the intersection of anthropology and archaeology, that includes everything from archaeological site analysis to long-term participant observation (Meskell 2012b). This hybridity very much applies to the study of international heritage regimes, a research focus within studying up which we will now briefly describe.

\section{Studying International Heritage Regimes}

When Nader published her liminal piece, focus was set on anthropology and specifically ethnography. Over time, the concept of studying up has spread to a range of disciplines, and even if the use of ethnography is still very common, it no longer holds primacy over other approaches. Some studies draw primarily on archival material (e.g. Gram-Skjoldager and Ikonomou 2019), while others are based on qualitative interviews (e.g. Trondal et al. 2010) or large N surveys (e.g. Christensen 1991). This is both due to changing research questions and the realization voiced by Gusterson $(1997,116)$ when revisiting Nader's call 25 years on, that studying up often means anthropologists need to do less participant observation, and rely more "on other research techniques for our field information." And so, researchers from anthropology to history, the political sciences and international relations, have advanced on institutions of power - such as the League of Nations, the EU institutions, the Organization of Economic Co-operation and Development, the World Trade Organization, the United Nations, as well as national and regional governance bodies (e.g. Christensen 1991; Shore 2000; Weiss 2009; Trondal et al. 2010; Adler and Pouliot 2012; Niezen and Sapignoli 2017; Gram-Skjoldager and Ikonomou 2019) - by way of various qualitative methods, combining 
archival material, ethnographic observations, interviews and surveys. What unites them is the upwards looking perspective and shared interest in understanding the inner workings of bureaucracies, the policies they produce and how they impact our lives. The study of international heritage regimes is part of this cross-disciplinary field of enquiry.

The interest for studying international heritage regimes has emerged among researchers in anthropology, folkloristics, geography, law, international relations and political science in the last decade (e.g. Schmidt 2009; Claudi 2011; Nielsen 2011; Brumann 2012; Bendix et al. 2012; Bendix 2013; Hamman 2017; Hafstein 2018). The concept of heritage regimes, as Geismar (2015) argues, enables us approach heritage as field of governance and politics rather than "thing" or "entity" and allows us to link different levels of governance to the implementation of policies. International heritage regimes represent legal conventions and norms which aim to bind international and national bureaucracies together. The resulting policies and guidelines often act in transformative and unpredictable ways on their journey to the ground, be it an archaeological site or a historic city center (e.g. Bendix 2012; Brumann and Berliner 2016; Duedahl 2016). Thus, while populated and driven by a range of actors, "the regimes themselves, as realized in unfolding bureaucratic institutions and processes, discipline both actors and their cultural practices into (perhaps) unforeseen dynamics" (Bendix et al. 2012, 16). Studying international heritage regimes therefore involves learning about regulatory frameworks, as well as the intentions and doings of actors who hold privileged positions in relation to specific regimes, i.e. actors with "more influence on political outcomes than general members of the public" (Richards 1996, 199). It means studying palpable, official aspects, and subtle norms and socialization processes within communities of professionals, experts, bureaucrats and politicians working in different tiers of national ministries, transnational agencies and international organizations. For the standard 
setting institutions of the EU and UNESCO, which are focus here, it means studying a combination of plenary assemblies, permanent secretariats and executive agencies.

As such international heritage regimes can be studied from multiple angles: Starting from the ground some have described life as it unfolds in World Heritage cities, where bureaucratic conservation measures clash with the practical needs of their $21^{\text {st }}$ century citizens (e.g. Ronström 2008; Johansson 2015). Others have tracked the processes leading up to 'heritage designations', be it for the UNESCO World Heritage or Intangible Cultural Heritage or the European Heritage Label, revealing how the journey from idea to status is comprised of intricate networks of community advocacy groups, civil servants and politicians who seek the status for radically different reasons (e.g. Tornatore 2012; Hølleland 2013; Halfstein 2018; Niklasson 2019). Attending the World Heritage Committee sessions, researchers have also looked at how expertise is deployed (James and Winter 2015) and exposed how "dubious diplomacy and savvy political jockeying" (Luke 2016, 641) have become part and parcel of seeking and keeping international heritage status (e.g. Meskell 2012a, 2016, 2018; Hølleland 2015; Bertacchini et al. 2016; Brown et al. 2019; Hølleland and Wood 2019). Yet others have tied into the subject by examining archaeology as a tool of economic development and national diplomacy (Luke and Kersel 2013; Samuels 2016, 2019; Luke 2018).

Starting from complex questions of how international heritage politics and governance "work", their analyses have drawn on various primary sources. Some rely mainly on written records to produce historical and statistical analysis (e.g. Titchen 1995; Jensen 2009; Labadi 2007, 2013; Lähdesmäki 2014, Källén 2014; Bertacchini et al. 2016; Hølleland and Phelps 2018; Niklasson and Hølleland 2018), others combine textual analysis with interviews or oral history (e.g. Calligaro 2011; Vos 2011; Gfeller 2013, 2015, 2017). Nevertheless, most researchers combine these sources with some form of "in situ" ethnographic fieldwork (e.g. Turtinen 2006; Schmidt 2009; Claudi 2011; Klimaszewski et al. 2012; Brumann 2012, 2014a, 
2017; Meskell 2012a, 2015, 2016, 2018; Hølleland 2013; Luke and Kersel 2013; James and Winter 2015; Akagawa 2015; Johansson 2015; Plets 2016; Niklasson 2016; Hafstein 2018; Luke 2016, 2018; Brown et al. 2019; Hølleland and Wood 2019). To acquire such information, they have entered the field from several different locations. One is as fullyfledged participants, in the role of interns or members of national delegations (e.g. Turtinen 2006; Nielsen 2011; Niklasson 2016; Hafstein 2018). Others have entered as observers, stressing their independent status (e.g. Brumann 2012; Hølleland 2013; Meskell 2015, 2018). A third type of position is that of insider researcher (e.g. Rao 2010; Jokilehto 2011; Cameron and Rössler 2013). In international heritage settings many civil servants - among them archaeologists - do institutional research and publish as part of their job. All of these positions are fluid and can change over the course of fieldwork, but as discussed in the next part, how you are situated has bearing on what challenges you face when studying up.

\section{Challenges and Strategies for Studying Up in Archaeology}

Far from an abstract idea, Nader's $(1972,301)$ challenge to study up was practical in nature: If researchers have less power than those being researched, she argued, it forces them to confront the interrelated issues of "access, attitudes, ethics and methodology". In the following we draw on our own experiences, and those described by others, to address three of the most common issues faced when applying a studying up perspective to heritage regimes. We start with the very basic issue of gatekeeping and gaining access. We then discuss the challenge of anonymity when researching close-nit communities of officials and experts where "everyone knows everyone". We end with an extended discussion on the complex issue of research reception. These challenges apply to most social and political studies trying to understand power relations in contemporary societies, especially if using ethnography. Yet we believe they are particularly important to for archaeologists considering studying up. For one thing, we are rarely trained in areas such as ethnography (Pyburn 2009; Zarger and 
Pluckhahnin 2013), making it a learning by doing experience that necessitate candid discussions on trial and error. Secondly, we are not just studying our own societies but our own professional sphere and an issue area - heritage - that we have a particular concern for. This mix of personal and professional stakes adds layers of complexity that calls for reflection.

\section{Gatekeeping in the civil service - the challenge of access}

One would think that gaining research access to official institutions would be relatively easy by virtue of laws on transparency and the right to information of public interest (Nader 1972, 302 - 303). Still, one of the key challenges facing those looking to study up is precisely how to enter the right settings (e.g. Gusterson 1997; Souleles 2018). This is in part due to gatekeeping practices, i.e. "the activity of controlling, and usually limiting, general access to something" (The Oxford English Dictionary 2019). When it comes to international bureaucracies like the UNESCO World Heritage Center or European Commission agencies, gatekeeping takes both passive and active forms. The hierarchical nature of bureaucracies, where "each official has a clearly defined sphere of competence within a division of labor and is answerable to superiors" (Barnett and Finnemore 2004, 17) can work as a passive gate keeper. The sharp lines that separate responsibilities are often invisible from the outside, making it hard to find who is actually covering the area under study. On top of this, there are basic safeguards in place to control what information can be shared with researchers and how, including confidentiality agreements for staff. Active gatekeeping occurs when these factors are employed strategically. Questions and topics outside the realm of responsibility of the official who receive them can be shuffled around and eventually go unanswered, and by selectively invoking information protection clauses, a single institutional representative can block access on behalf of an entire organization. 
When the political dimensions of unfolding heritage processes are strong, gatekeeping often intensifies. Even though bureaucracies are set up to be impersonal, and work is to be "conducted according to prescribed rules and operating procedures that eliminate arbitrary and politicized influences" (Barnett and Finnemore 2004, 17), this situation rarely resembles reality. The same can be said for the ideal that officials "selected according to merit are trained for their function" (Barnett and Finnemore 2004, 17), a standard which varies greatly (Weiss 2009, 109; also Hoggart 2011[1978]). When going into detail, researchers are likely to show individuals' agency and how political bargaining influences decision-making (e.g. Gfeller 2013, 2015, 2017; Meskell 2014, 2015, 2016; Niklasson 2017; Hølleland and Phelps 2018). To protect status quo, officials and civil servants may therefore use the ideal of neutrality to avoid interacting with researchers. When Tornatore $(2012,343)$ studied the highly politized listing of "The Gastronomic Meal of the French" under UNESCO's Representative List for Intangible Cultural Heritage, he struggled to get informants to play the "ethnographic interview game". The only thing he received was carefully crafted statements and minutes from meetings. Similarly, Niklasson (2016) found that while EU officials often agreed to be interviewed, administrative staff declined by referring to the non-political nature of their position.

The issue of gatekeeping can also occur when the research has a historical dimension as there may be obstacles when trying to access archival data. As Barnett and Finnemore $(2017,17)$ notes, civil servants hold the key "to knowledge stored in files", and with the backing of institutional archival policies that restrict access to files younger than 20 years in UNESCO and younger than 30 years in the EU, it is sometimes easier to look for duplicates or related files in national or personal archives. Furthermore, as Hølleland $(2013,33)$ discovered, even when given access, patchy recording systems can turn the task of locating older records into a journey through garages and lofts for both researcher and organizational 
staff. At times files are simply missing, their whereabouts unknown; some may have been removed intentionally, others have been lost due to poor storage facilities. In sum: "[s]tudying 'up'... is difficult: any study of the powerful focuses on people and institutions with power to exclude themselves from the realm of the discussable" (Cooper and Packard 1997, 5).

\section{STRATEGIES FOR GAINING “IN SITU” ACCESS}

After identifying the research locale, the first threshold is gaining access to the right settings or people. Many institutions do not have an official procedure for such requests, and even when they do, as in the case of UNESCO and the EU, sending an official request or filling out a web form rarely does the trick. The researcher can easily be led into a circus of interinstitutional email shuffling, and risk ending up with a blank "no", or not being admitted to an (international) meeting (e.g. Brumann 2012, 8). Some groundwork may be needed ahead of gaining access, especially as participant observer or intern. For example, when applying for an EU internship, Niklasson learned from previous interns that you need to lobby the unit you want to work for by pitching yourself and your interests in personal emails to EU officials. When the emails garnered hostile responses, stating that lobbying was forbidden, she feared the race was lost. But the same unit that sent the hostile responses ended up selecting her, and afterwards they said they had liked her email (Niklasson 2016, 125).

Once inside, researchers face the next threshold: to gain the "right" kind of access. Both in terms of the information sought, i.e. the stuff that you cannot read in policy pamphlets, and the settings in which you can find it. As Brumann (2012) notes, to sit in the back of the room during a World Heritage Committee session - listening, watching and taking notes - gives you at best a partial idea of what is going on, not too different from the understanding you could have gained by watching the live streaming from home. Rather, it is at restricted meetings, coffee breaks, lobbying and "side" events outside of the immediate locale that alliances are formed, and political bargains are struck (e.g. Meskell 2015). Getting 
such access is a matter of establishing rapport/trust and find informants that can act as door openers (Turtinen 2006).

\section{STRATEGIES FOR BUILDING RAPPORT AND GAINING TRUST}

Just as in any ethnographic encounter, a common place to start when looking to gain trust is with appearance, speech and knowledge. By adopting a similar dress code to the people inhabiting the site, a certain acceptance can be gained (Brumann 2012, 10). As Hølleland $(2013,277)$ experienced when moving between local and international heritage locales, this is not just the case for researchers. When running into a key informant at a World Heritage Committee session in Paris, both remarked upon the stark contrast between their freshly ironed shirts and the causal khaki attire of the regional office in New Zealand where they first met. The fact that studying up often means dressing up, is not unproblematic. During her first days at the European Commission, Niklasson realized that a clean outfit was not always enough, it should preferably look new and be of an expensive brand. While this was difficult to achieve on an internship stipend, it could present a far more serious obstacle to researchers from low-income regions, on top of already expensive travel bills.

When it comes to speech, using the same jargon as potential informants can sometimes be more important when studying up than sharing a language. While casually using abbreviations such as "OUV" or "SOC" may facilitate conversation in a World Heritage setting, adapting to the "Eurospeak" used by EU civil servants can open doors in Brussels. It can also lead to new research findings. As Niklasson got familiar with the French-English hybrid phrases and abbreviations used in EU institutions, she realized that the ability of heritage practitioners to use such phrases and buzzwords had bearing on their success in the battle for EU funding (Niklasson 2016). Another important prerequisite is knowing the political and institutional history. For the World Heritage regime; knowing the historic controversies surrounding the convention helps one appreciate how states strategically use 
official polices, such as the "Global Strategy", to facilitate the listing of nominations with poor evaluation results (e.g. Hølleland and Wood 2019). In these international settings, as in many others, demonstrating knowledge of common procedures, key documents, sites or policies will lend credibility and reveal you as a potential asset to the people you talk to. The second step is to establish a handful of core contacts to "snowball" from. By having such a core group that can help introduce you to others, and by dropping their names in conversation, a web can be grown. While a common strategy in ethnographic research, snowballing can take a long time when studying up due to a lot of the communication happening at a distance, and because you are not just asking people to participate as individuals on their free time, but in the capacity of professionals while they are in the middle of work. Letters and follow-up telephone calls are necessary when requesting permissions and making interview appointments (Meskell 2016, 74), even if they often go unanswered (Brumann 2012, 11), but it is essential that digital communication is combined with face to face meetings. Rather than "cold-emailing" people of interest, it was through verbal requests made on-site and follow-up emails that Brumann managed to get interviews with diplomats, civil servants and heritage experts tied to UNESCO (Brumann 2012, 11). Similarly, Niklasson (2016) was only able to get forthcoming responses from the heritage experts that reviewed EU grant proposals after she had met them in person in Brussels.

Due to the need of having some form of access before gaining access, and because the web of informants is always dependent on who is in "group zero" - how they are situated organizationally and socio-politically - the research is bound to develop organically and have unpredictable outcomes. If you begin as a representative in a national delegation to the World Heritage Committee, as Turtinen did, the knowledge gained will be conditioned by the position of that delegation, limiting and extending access in certain directions. If you, as Brumann, Hølleland and Meskell, begin your participatory ethnography without any strong 
predefined allegiances, you may spin a wider and more randomized web, but one predisposed toward the most visible, accessible and outwardly powerful candidates (and who may have agendas of their own). Combined with the multi-sited nature of international heritage regimes, ethnographic accounts can therefore only ever be partial, something which in turn has bearing on issues of consent and anonymity.

\section{Ethical issues when "everyone knows everyone" - the challenge of anonymity}

Upon starting a research project most research institutions require one to fill out ethics forms on how to handle issues of consent and anonymity of informants. While obtaining these permits are essential and facilitates reflection on the practicalities of ethics ahead of entering the field, it does not necessarily prepare you for the field situation.

When conducting formal interviews, consent forms are often easily handled. Signing, or even explaining the purpose of the research, does not necessarily ensure understanding, however. Informants may, as Hølleland $(2013,44)$ encountered, insist they “don't need a copy" or gently put the form in the recycling bin. Consent may also be given based on the assumption that the researcher and informant share an "ideological stance on heritage". Brumann (2014b) points out that many who work with heritage in a professional capacity are "heritage believes". By this he means they are, personally or as a part of a commitment to their work, convinced that cultural heritage is intrinsically valuable and good (Brumann 2014b, 173-174). If it becomes apparent during the interview or after, that the researcher takes a much more negative stance on heritage, it can undermine consent by creating a sense of betrayal (Brumann 2014b, 174). While most archaeologists studying up have a nuanced understanding of heritage, it is important to consider how to communicate our position before we enter the field as it will impact how we build rapport and gain trust.

Consent is also difficult to obtain in the heat of the moment, when casually discussing events during a coffee break. Yet as a researcher you cannot necessarily ignore the 
information; indeed, at times it may change your view on a matter entirely. This is particularly challenging if your dual role as a participant and researcher may not be known to informants (e.g. Turtinen 2006). You can also be faced with similar problems if you come across archival documents marked "withdrawn from public access", which archivists have not pulled out of the file. While uncitable, you cannot unlearn what you found there. Thus, most researchers have to find a way to deal with information without directly using it or citing the source. Strategies for how to approach this issue is directly linked to of the issue of anonymity.

When studying up, the pool of actors is not only modest, the official roles actors hold can also make them easily identifiable: Their names may appear on staff webpages, on lists of participants for meetings, on official documents and so on. As Meskell notes, "new appeals for transparency at UNESCO and extensive documentation including web-streaming and posted transcripts from World Heritage Committee meetings renders most individuals increasingly identifiable" (Meskell 2018, 21). Other professionals operating in the same field are also likely recognize the views and language of colleagues. As Verlot $(2001,352)$ points out, "the origin of the information is quite clear to those in the "inner sanctum", and as Kuus $(2014,50)$ states in her study of EU officials: "An experienced commission official can potentially tell a Brit by peculiarly British idioms, a Pole by specific choices in English sentence structure". Thus, whereas anonymity is often the golden standard in research ethics applications, complete anonymity is impossible when studying up.

\section{STRATEGIES FOR HANDLING ISSUES OF ANONYMITY}

While anonymity is at best partial and hard to guarantee, most researchers go to some length in concealing the identity of informants. A basic strategy is to use aliases or descriptive categories such as "mid-level government official", "high-level diplomat" or "ambassador", or to generically refer to "member of X delegation". This can be combined with "blurring or 
slightly altering the details, and ... [not pointing out] when a mentioned informant is also the author of a [cited] text” (Brumann 2012, 12). Yet as Brumann $(2012,21)$ succinctly points out, "Hiding the central organizations of the World Heritage arena would render everything pointless".

Another strategy to anonymize informants is what can loosely be called "proofing". By this we refer to an approach somewhere between journalistic methods and regular triangulation, when researchers try to build a case around something they already know to be true, but which cannot be stated plainly or be backed up with quotes. The first thing to consider is of course whether the information - be it an argument you witnessed over lunch, a transgression described in an interview, or a personal complaint in an unregistered letter found in the archives - really adds something to the analysis. If it does, "proofing" can be done by conducting a directed search for circumstantial evidence of the matter, or similar matters. Places to look can be in minutes of meetings, transcripts of proceedings or speeches, official correspondence, reports, newsletters, or other documentary information which often exists online and in public archives. Alternatively, a revealing story told by an informant can be stripped of case specific elements and be rephrased as a hypothetical question or scenario in interviews with other informants. The latter is particularly useful if the researcher is not looking for how and when something occurred, but to identify attitudes and power dynamics. When successful, the ethnographic observations can be presented as supporting information that are already in the public domain, minimizing the risk that individuals are exposed (e.g. Meskell 2016). When working at the EU agency, Niklasson (2016) observed several aspects related to institutional culture that influenced the selection of archaeological projects for funding, and in turn, what visions of the past was deemed desirable. These aspects involved the language and nationality of civil servants, favoritism in the selection of external reviewers, and the sidelining of official procedure to avoid inter-institutional conflict. By 
drawing on the insights of anthropologists studying other parts of the European Commission, and sifting through official evaluations, reports, and archival documents about the agency and its cousins in the EU framework, a broader account could be built around the observed patterns which did not rely on individual voices.

At times, however, identifying individuals is of the very essence, both in terms of scientific adequacy and ethics. After all, those being studied - and this is especially true in ethnography - are co-creators in the knowledge production (Holmes and Marcus 2005a, b, $2008 \mathrm{a}, \mathrm{b})$. If they wish to be named, researchers need to consider their motivations and negotiate what form recognition should take. Moreover, when studying historical developments, such as the long process of World Heritage nominations or the creation of new policies, leaving names out may rob individuals of agency and dissolve important nuances. It can also make the accounts incomprehensible for readers. In these instances, a useful strategy is to combine archival records with oral history, whether as informal or recorded conversations. Indeed, showing, asking about, or searching for archival records together with the informant often triggers memories and reflections which invite discussion. Going through the files of a World Heritage nomination with Hølleland for the first time since the site was nominated, one informant remarked somewhat frustrated that "the big picture disappears in the trivia"' (Hølleland 2013, 34). This became the basis for lengthy conversations which exposed a complex history. In order to be readable and to give actors agency, the solution was to name individuals and discuss recognition together based on transcripts and draft chapters. By carefully drawing on archival documents like this, a timeline of events and the role of individuals can be presented in a rich manner that help craft a sense of narrative trust and facilitate future interactions with informants (e.g. Gfeller 2013, 2015, 2017; Hølleland 2013).

Lastly, although precautions should always be taken, researchers studying international heritage bureaucracies have to accept that they operate within a sphere where 
those familiar with the field will hardly be hard-pressed to identify informants. This is why the next challenge of research reception becomes a critical juncture when studying up.

\section{Burning or building bridges - the challenge of negotiating research reception}

No heritage researcher is so naïve as to assume that their academic articles or books will be widely read by groups linked to the settings under study (or even by other academics). Nevertheless, when we study our own societies and write in the language of our informants, the native readership grows (Brettell 1993). Not only are informants in such settings often highly educated and involved in analytical exercises that resemble our own (Holmes and Marcus 2005a, 2008a), but when our field of expertise overlaps with that of our informants, certain expectations apply.

When approaching an institution from the outside, researchers may be called upon to act as advisors or to provide a type of free institutional evaluation. Meskell describes being asked by a UNESCO employee to come up with an official definition for an "archaeological site", something that had never been clearly articulated by the organization (Meskell 2018, 17). Seeing as such definitions, or the lack of them, is a central theme for those studying UNESCO and something shown to have far reaching consequences, agreeing to such requests alters the stakes for both researchers, informants and those who work towards a World Heritage listing. Meskell further mentions the issue of overlapping spheres in relation to her experiences at the World Heritage Centre, when she notes: "Some members of UNESCO's Secretariat, however, have expected a level of allegiance from me that is not possible to maintain if multiple viewpoints are to be represented, sometimes leading to antipathy and even threats" (Meskell 2018, 22).

If conducting research from within the organization, the leadership may expect direct policy input or claim co-ownership of the results. This is more acute in areas such as evaluation research, where scholars speak of organizations both setting the research criteria 
and actively censoring results they do not approve of (Storeng and Palmer 2019), but archaeologists who study heritage regimes also face difficult situations. In UNESCO or the EU, research results may come up at meetings, appear in reports, or be openly rebutted. As Brumann $(2012,12)$ reflects after discovering his own texts and statistics used in UNESCO documents: "[I] find myself in a postmodern field situation with all kinds of feedback loops". While such feedback loops are positive and indeed a prerequisite if any obstacles to change identified through the research are to inspire actual change, conflicts can occur when the native readership perceives the results as too negative. Added to this, ethnographic accounts may have a certain "gossip value", with informants trying to locate "who said what" (Davis 1993), or even use the information as leverage in internal conflicts. Combined with the issues of anonymity and the often-delicate nature of the information uncovered, much may therefore be at stake when it comes to publishing.

One of the major things at stake is the professional reputation and legitimacy of the people and the organization under study. Nader $(1972,305)$ suggests that, although facing the same ethical challenges, studying "up" and "down" has different consequences. When studying private or semi-private spheres, especially if the research has an emancipatory focus, writing about a questionable decision or exposing a case of misconduct can have an empowering effect. The opposite is true when studying organizations that rest on moral authority, established to serve a "common good". To scrutinize those best positioned to influence heritage policy may be important from a democratic perspective. But to reveal that the official image of a public institution stands in sharp contrast to its inner workings, or that civil servants are making political decisions, may weaken claims to authority, affect job security for identifiable civil servants, and ultimately harm those the organization aims to serve. 
This is why researchers working inside an organization are much more likely to write about informal or questionable practices once they have left (e.g. Hoggart 2012[1978]; Cleere 2011). When conducting research from within, critique has to take a more moderate form, often structured around “improving practice” (e.g. Rao 2010; Hølleland and Johansson 2019 for further examples). When approaching the institution from outside, less favorable findings risk feeding into public critique. When studying the inner workings of the EU, Niklasson realized that by describing the sometimes self-serving and ad-hoc nature of the bureaucratic processes she witnessed, her results could play directly into the hands of anti-EU advocates. After being interviewed about her research on Swedish radio and in news outlets (Sveriges Radio 2015; SVT 2016), she found it referenced online as evidence for the idea that the EU is a manipulative and broken organization. Even if researchers' descriptions of unofficial practices are unlikely to topple large multilateral institutions like the EU, they may contribute to increased audits of smaller government-funded organizations, which might, in turn, lead to restructures or closures (e.g. Ibenholt et al. 2013).

Another thing that may be at stake is the researcher's ability to conduct further research in the same setting. Examples of situations in which archaeologists have been forced to exit a specific setting due to the hostile reception of their results are hard to come by, perhaps because such confessions can cast doubt on the ethics and validity of the research in question. This is surely one of the reasons why Mosse's (2006) candid account of the negative reception of his work has become so formative in anthropological discourse. Another reason is likely that negative reception is rarely so dramatic. Upon pursuing a new research project on a closely related EU topic, Niklasson was not met with protests as much as a deliberate coldness by some former colleagues. They were clearly aware of her publication, not least due to pre-publication efforts to anchor the results, but they were not entirely happy about its contents, and rather than seeking confrontation they decided to not engage further. 
Lastly, publishing the results can affect researchers' possibilities of future employment. To study up almost always involves scrutinizing the glue that holds communities of experts and civil servants together, the telling mistakes, the omissions, and the "moments of accommodation, complicity, and seduction" that drive "processes of ongoing socialization" (Brenneis 1994, 26). When those communities intersect with researchers' own professional spheres, publishing often involves having to bite the hand that feeds- or may feed you. If positioned inside the organization, negative reception can result in colleagues and sometimes friends feeling betrayed, which may affect job security in the long term. If positioned outside, negative reception may still affect your reputation and prospects for future employment. If an archaeological ethnographer aspires to enter an international heritage bureaucracy, recounting for instance the subjectivity of UNESCO's advisory bodies and their evaluations can be a risky business. The same goes for writing about contested World Heritage sites - as attested by a research colleague who was advised by UNESCO actors to drop her study in order to avoid ruining future job chances.

While these challenges should never inhibit publishing or lead to a watering down of the results, they do require the researcher to make a series of choices and call for a heightened sensitivity when it comes to how certain truths are presented.

\section{STRATEGIES FOR HANDLING RECEPTION}

A first strategy that can be adopted to mitigate negative reception in situations where writing about unofficial information may damage the reputation and legitimacy of the organization and its staff, is to "humanize" the people under study. Beyond understanding the basic codes of conduct that govern their work, recognizing for instance that a reluctance to engage in ethnographic dialogue may have more to do with staffing regulations or "the seven duties guiding the civil service" (e.g. LGM 2019) than active gatekeeping, there are also emotive aspects to consider. In critically addressing Cris Shore's anthropological work on EU officials 
(2000), Verlot (2001) calls upon researchers studying up to recognize that "elites are humans too". Verlot argues that we must acknowledge the doubts and pressures that comes with responsibility and everyday decision-making. Only then can we can avoid the trap of coming to see informants as "bodies characterised by unity and common function" (Verlot 2001, 351). In practice this means sacrificing some of the explanatory power offered by stereotypes like the "self-serving elite", in exchange for the nuance gained by augmenting circumstantial factors. To paraphrase Clifford Geertz $(1974,29)$ famous statement, that the goal in ethnography is to "figure out what the devil they think they are up to", the task at hand, thus, is to figure out what circumstances conspired to put them up to it. Added to this is the question of who the unofficial information serves. If we find that it may play into the hands of actors seeking retaliation or excuses to undermine the organization, we need to make very clear what the results do not mean - what situations they can and cannot speak to.

Another strategy, concerning the issue of overlapping spheres, is to pursue a form of epistemological cooperation, or what Holmes and Marcus calls "para ethnography" (2005b, 2008a, 2008b). They suggest that, when researcher and informant operate within the same sphere, field of expertise, or are involved in similar types of intellectual labor, researchers should experiment and work collaboratively with informants. This means discussing results with informants throughout the research process, to let them read and react to observations and to incorporate those reactions and corrections - whether encouraging or hostile - into the final interpretation. A few months after Niklasson interviewed a leader of an EU-funded project about issues like European identity and reflexivity in archaeological practice, the informant published an academic article reflecting on precisely what they had discussed. This could be seen as the informant "stealing the show" (and at first this is how it felt), but when approaching the situation from a para-ethnographic viewpoint, the article became an addition to the empirical base and a reason for continued discussion with the informant. Combined 
with the strategies of "proofing" and using historical sources, such collaboration can ensure that the published results are more ethically grounded and "buyable" for the native readership. It can also make them more useful. For instance, some time after Hølleland's (2013) study was completed, her "archival excavations" served as a valuable backdrop when the organization needed to create a retrospective statement of Outstanding Universal Value.

All these strategies sound good in theory, but to humanize the people under study and collaborate will only get you so far. Unless researchers actually co-author with informants, a practice which can, depending on the nature of the findings, dull the critical edge of studying up, the final interpretation is always the responsibility of the researcher. And sometimes, no matter how careful, the very nature of ethnographic enquiry - with its focus on everyday contradictions, compromises and personal agency - will inevitably clash with the "legitimate fictions" international bureaucracies like to tell about themselves (Mosse 2011). When this happens, one strategy is to face the accusations standing up and incorporate them in your future work. This means to contest claims of inaccuracy and potential damage by going over with the accusers, exactly what passages and details they consider to be erroneous or damaging. It was when Mosse $(2006,944)$ did so that he realized how the organization's approach to knowledge hinged upon the idea of "fairness". How something being factually accurate did not make it "correct". To be correct the interpretation would require consensus and respect: "they felt that the moral nature of their actions should shape the way they were described" (Mosse 2006, 945). In the end, Mosse used the insights gained from the conflict as a base for further research. Another strategy, and last retort, is to burn bridges strategically; there is a reason why researchers studying international heritage regimes from an inside position tend to publish once they are no longer employed by the organization. And when it comes to researchers approaching institutions from the outside, they may find more room to be openly critical when tenured and well-established in their field. 


\section{Final Reflections}

In this article we have tried to do two things. The first was to argue for the importance of "studying up" in archaeology, in order to better understand the political and bureaucratic settings in which tomorrow's sanctioned understanding of heritage is formed. Drawing on Nader's call (1972) to enter into contexts where the researcher has less power than the people or organizations under study, we suggested that this approach can help increase scientific adequacy and democratic relevance in the field of enquiry that deal with the values and politics of archaeology and heritage. In part by securing a temporally balanced perspective and complicating the image of "the expert" alongside that of "the public", and in part by opening a window for disciplinary and institutional self-reflection, and allowing stakeholders to learn about otherwise hidden aspects of heritage processes.

The second task was to introduce international heritage regimes as a research focus and reflect on what it means to study up in a methodologically stringent and ethically justifiable manner. To study up in an area which entails such a wide array of disciplines and hybrid methodologies, we argued, is essentially about perspective, and about a shared set of challenges that this perspective invokes. Some of which are particularly thorny when researching one's own professional sphere. Here we discussed everything from gate-keeping practices, which can make it difficult to gain access to institutions, archives and people, to ethical issues concerning the effects of writing about unofficial practices or documents not meant for public eyes. Other challenges concerned the communities of heritage professionals and civil servants that inhabit the settings of UNESCO and the EU: How tight-knitted networks can create issues of anonymity, and how the dynamic between the field and fieldworker has bearing on everything from what researchers will be able to learn to the reception of the published results. If there is one overarching message that can be extracted from this discussion, it is that researchers studying up need to increase the transparency of 
their work. To study up in archaeology is in many ways a learning by doing experience. It is therefore vital to share our experiences, both successes and failures.

In today's increasingly polarized political landscape, where "archaeology is consistently being used by political interests, often to make nationalist and xenophobic claims" (Nilsson Stutz 2018, 54), and where austerity measures and reforms in the heritage sector are mounting, researchers have called for an archaeology that provokes and teaches, and for a re-evaluation of the role of the expert (e.g. Richardson 2017; Fredheim 2018; González-Ruibal et al. 2018; Hølleland and Skrede 2019; Nilsson Stutz 2018). Within this context of introspective, yet heated, discussions about disciplinary futures, we believe that "studying up" represents an opportunity and a necessity. If we are to "return to the roots of politics" and cultivate a "critical voice" that can provide insightful diagnosis, counsel and public commentary (González-Ruibal et al. 2018, 513), we need to empirically examine the actors and conditions that govern archaeology and heritage. Because when we do, we often find that they are not who or what we first thought they were. To gain these insights, and to create a solid base upon which our research can be (re-)integrated into archaeology and other disciplines, require that we build a tradition for openly reflecting on how (not) to study up.

\section{Acknowledgement}

The article is in large part a result of our time working together at Stanford Archaeology Centre (SAC). Thus, Hølleland would like to thank the Norwegian Research Council for its HUMEVAL grant and Prof. Lynn Meskell for her invitation to SAC, both of which that enabled her stay. We would also like to thank the reviewers for their detailed and constructive feedback on the draft paper.

\section{Author's Contribution}

Both authors have contributed equally to the data collection, analysis and writing of this article.

\section{Literature}

Adler, Emanuel, and Vincent Pouliot. 2012. International Practices. Cambridge: Cambridge University Press.

Akagawa, Natsoku. 2015. Heritage Conservation in Japan's Cultural Diplomacy. Heritage, National Identity and National Interest. London: Routledge. 
Barnett, Michael, and Martha Finnemore. 2014. Rules of the world. International organizations in global politics. Ithaca/London: Cornell University Press.

Bendix, Regina F. 2013. "The Power of Perseverance. Exploring Negotiation Dynamics at the World Intellectual Property Organization." In Gloss of Harmony: The Politics of Policy-Making in Multilateral Organisations, edited by Birgit Müller, 23-49. London: Pluto Press

Bendix, Regina F., Aditya Eggert and Arnika Peselmann. 2012. Heritage Regimes and the State. Göttingen Studies in Cultural Property 6. Universitätsverlag Göttingen.

Berg, Ingrid. 2016. Kalaureia 1894: a cultural history of the first Swedish excavation in Greece. $\mathrm{PhD}$ diss, Stockholm University.

Bertacchini, Enrico, Claudia Liuzza, Lynn Meskell, and Donatella Saccone. 2016. "The politicization of UNESCO World Heritage decision making." Public Choice 167, no. 1: 95-129. doi: 10.1007/s11127-016-0332-9.

Bonacchi Chiara, Mark Altaweel and Marta Krzyzanska. 2018. "The heritage of Brexit: Roles of the past in the construction of political identities through social media." Journal of Social Archaeology 18, no. 2:174-192.

Brettell, Caroline B., ed. 1993. When They Read What We Write: The Politics of Ethnography. London: Bergin \& Garvey.

Brenneis, Donald. 1994. "Discourse and Discipline at the National Research Council: a Bureaucratic Bildungsroman." Cultural Anthropology 9, no. 1: 23-36. https://doi.org/10.1525/can.1994.9.1.02a00020

Brumann, Christoph. 2012. "Multilateral Ethnography: Entering the World Heritage Area." Max Plack Institute for Social Anthropology Working Papers no. 136. Halle/Saale.

Brumann, Christoph. 2014a. "Shifting Tides of World-making in the UNESCO World Heritage Convention: Cosmopolitanisms Colliding." Ethnic and Racial Studies 37, no. 12: 2176-2192. https://doi.org/10.1080/01419870.2014.934261

Brumann, Christoph. 2014b. "Heritage Agnosticism: A Third Path for the Study of Cultural Heritage." Social Anthropology/Anthropologie Sociale 22, no. 2: 172-188. https://doi.org/10.1111/14698676.12068

Brumann, Christoph. 2017. "The Best of the Best: Positioning, Measuring and Sensing Value in the UNESCO World Heritage Arena." In Palaces of Hope: The Anthropology of Global Organizations, edited by Ronald Niezen, Maria. Sapignoli, 245-265. Cambridge: Cambridge University Press.

Brumann, Christoph, and David Berliner. 2016. World Heritage on the ground. Ethnographic perspectives. London/New York: Berghahn.

Byrne, Dennis. 1991. "Western Hegemony in Archaeological Heritage Management." History and Anthropology 5, no. 2: 269-276. https://doi.org/10.1080/02757206.1991.9960815

Calligaro, Oriane. 2013. Negotiating Europe: EU Promotion of Europeanness Since the 1950s. New York: Palgrave Macmillan.

Cameron, Christina and Mechtild Rössler. 2013. Many voices, one vision: the early years of the World Heritage Convention. London: Routledge.

Castañeda, Quetzil E. 2008 “The 'ethnographic turn' in archaeology: research positioning and reflexivity in ethnographic archaeologies." In Ethnographic archaeologies: reflections on stakeholders and archaeological practices, edited by Queztil E. Castañeda, Richard Handler, Julie Hollowell, Mark P. Leone, George Nicholas, K. Anne Pyburn, and Larry J. Zimmerman, 25-61. Oxford: AltaMira.

Childe, Gordon. 1933. "Race, Peoples and Cultures in Prehistoric Europe". History 18: 193-203.

Christensen, Tom. 1991. "Bureaucratic Roles: Political Loyalty and Professional Autonomy." Scandinavian political studies New series. 14, no. 4: 303-320. https://doi.org/10.1111/j.14679477.1991.tb00121.x

Clarke, David. 1973. "Archaeology: the loss of innocence”. Antiquity XLVII: 6-18.

Claudi, Ida B. 2011. "The New Kids on the Block : BRICs in the World Heritage Committee." MPhil thesis. University of Oslo.

Cleere, Henry. 2011. "The 1972 UNESCO World Heritage Convention.” Heritage and Society 4, no. 2: 173-186. https://doi.org/10.1179/hso.2011.4.2.173 
Cooper, Frederick, and Randall Packard. 1997. "Introduction." In International Development and the Social Sciences, edited by Frederick Cooper and Randall. Pandey, 1-45. Berkeley: University of California Press.

Davis, Dona L. 1993. "Unintended Consequences: The Myth of 'the Return' in Anthropological Fieldwork." In When They Read What We Write: The Politics of Ethnography, edited by Caroline Brettell, 27-35. London: Bergin \& Garvey.

Díaz-Andreu García, Margarita. 2007. A world history of nineteenth-century archaeology : nationalism, colonialism, and the past. Oxford: Oxford University Press.

Díaz-Andreu, Margarita, and Timothy Champion. 1996. Nationalism and archaeology in Europe, London: Routledge.

Edgeworth, Matt, ed. 2006. Ethnographies of archaeological practice: cultural encounters, material transformations. Oxford: Altamira.

Ferguson, Natasha. 2016. "Lost in Translation: Discussing the Positive Contribution of Hobbyist Metal Detecting." Open Archaeology 2, no. 1: 115-126.

Fredheim, L. Harald. 2018. "Endangerment-driven Heritage Volunteering: Democratisation or 'Changeless Change'." International Journal of Heritage Studies 24, no. 6: 619-633. https://doi.org/10.1080/13527258.2017.1399285

Gannon, Megan 2019. "When Ancient DNA Gets Politicized." Smithsonian, July 12. URL: https://www.smithsonianmag.com/history/when-ancient-dna-gets-politicized-180972639/ (accessed 26 September 2019).

Gardner, Andrew. 2018. "Power, Knowledge and the Past." Antiquity 92, issue 366: 1662-1664. https://doi.org/10.15184/aqy.2018.232

Geertz, Clifford. 1974. "“From the Native's Point of View': On the Nature of Anthropological Understanding." Bulletin of the American Academy of Arts and Sciences 28, no. 1: 26-45.

Geismar, Haidy. 2015. "Anthropology and Heritage Regimes." Annual Review of Anthropology 44: 71-85.

Gfeller, Aurélie Elisa. 2013. "Negotiating the Meaning of Cultural Heritage: 'Cultural Landscapes' in the UNESCO World Heritage Convention 1972-1992.” Journal of Global History 8, no. 3: 483-503.

Gfeller, Aurélie Elisa. 2015. "Anthropologizing and Indigenizing Heritage: The Origins of the UNESCO Global Strategy for a Representative, Balanced and Credible World Heritage List." Journal of Social Archaeology 15, no. 3: 366-386.

Gfeller, Aurélie Elisa. 2017. "The Authenticity of Heritage: Global Norm-Making at the Crossroads of Cultures." American Historical Review 122, no. 3: 758-791.

González-Ruibal, Alfredo, Pablo A. González and Felipe Criado-Boado 2018. "Against Reactionary Populism: Towards a New Public Archaeology.” Antiquity 92, no. 362: 507-515. https://doi.org/10.15184/aqy.2017.227

Gram-Skjoldager, Karen., \& Ikonomou, Haakon. A. 2019. "Making Sense of the League of Nations Secretariat - Historiographical and Conceptual Reflections on Early International Public Administration." European History Quarterly, 49, no. 3: 420-444. https://doi.org/10.1177/0265691419854634.

Gusterson, Hugh. 1997. "Studying up revisited." Political and Legal Anthropology Review 20, no. 1:114-119.

Hafstein, Valdimar T. 2018. Making Intangible Heritage. El Condor Pasa and Other Stories from UNESCO. Bloomington: Indiana University Press.

Hakenbeck, Susanne E. 2019. "Genetics, archaeology and the far right: an unholy Trinity." World Archaeology, DOI: 10.1080/00438243.2019.1617189

Hamilakis, Yannis. and Philip Duke eds. 2007. Archaeology and capitalism: from ethics to politics. Walnut Creek, CA: Left Coast.

Hamilakis, Yannis. 2011. "Archaeological Ethnography: A Multitemporal Meeting Ground for Archaeology and Anthropology." Annual Review of Anthropology 40: 399-414.

Hamilakis, Yannis. 2018a. "Decolonial Archaeology as Social Justice." Antiquity 92, no. 362: 518-20.

Hamilakis, Yannis., ed. 2018b. The New Nomadic Age. Archaeologies of Forced and Undocumented Migration. Equinox Publishing. 
Hamman, Evan. 2017. "The Role of Non-state Actors in Promoting Compliance with the World Heritage Convention: An Empirical Study of Australia's Great Barrier Reef.” PhD thesis, Queensland University of Technology.

Hoggart, Richard. 2011[1978]. An Idea and Its Servants. UNESCO from Within. New Brunswick/London: Transaction Publishers.

Holmes, Douglas R. and George E. Marcus 2005a. "Refunctioning ethnography. The challenge of an anthropology of the contemporary". In The SAGE Handbook of Qualitative Methods, edited by Norman K. Denzin and Yvonna S. Lincon, 1099- 1013. London: Sage Publications.

Holmes, Douglas R. and George E. Marcus. 2005b. "Cultures of Expertise and the Management of Globalization: Toward the Re-functioning of Ethnography." In Global assemblages: Technology, Politics, and Ethics as Anthropological Problems, edited by Aihwa Ong and Stephen J. Collier, 235-252. Malden, MA: Blackwell Publishing.

Holmes, Douglas R. and George E. Marcus. 2008a. "Para-ethnography." In The Sage Encyclopaedia of Qualitative Research Methods, edited by Lisa M. Given, 596-597. Thousand Oaks, CA: Sage.

Holmes, Douglas R. and George E. Marcus. 2008b. "Collaboration Today and the Re-imagination of the Classic Scene of Fieldwork Encounter." Collaborative Anthropologies 1: 81-101. https://doi.org/10.1353/cla.0.0003

Hølleland, Herdis. 2013. "Practicing World Heritage. Approaching the Changing Faces of the World Heritage Convention." PhD diss, University of Oslo.

Hølleland, Herdis. 2014. "Mt Ruapehu's looming lahar. Exploring mechanisms of compliance in the World Heritage regime." In Between dream and reality: Debating the impact of World Heritage Listing. Primitive tider special edition 2014, edited by Herdis Hølleland and Steinar Solheim, 75-92. Reprosentralen, Oslo.

Hølleland, Herdis. 2015. “35 COM 8B.27 Refleksjoner rundt verdensarvbeslutninger.” In Inn i fortida - ut i verden - i museet, edited by Jon Anders Risvaag, Ragnhild Berge and Terje Brattli, 106128. Trondheim: Museumsforlaget.

Hølleland, Herdis and Marit Johansson. 2019. ““. . . To Exercise in All Loyalty, Discretion and Conscience': On Insider Research and the World Heritage Convention.” International Journal of Cultural Policy 25, no. 3: 309-321. https://doi.org/10.1080/10286632.2017.1301933

Hølleland, Herdis, Evan Hamman, and Jessica Phelps. 2019. "Naming, Shaming and Fire Alarms: The Compilation, Development and Use of the List of World Heritage in Danger." Transnational Environmental Law 8, no. 1: 35-57. http://dx.doi.org/10.1017/S2047102518000225

Hølleland, Herdis and Jessica Phelps. 2018. "Becoming a Conservation 'Good Power': Norway’s Early World Heritage History.” International Journal of Cultural Policy Online first: 1-18. https://doi.org/10.1080/10286632.2018.1431223

Hølleland, Herdis and Joar Skrede. 2019. "What's Wrong with Heritage Experts? An Interdisciplinary Discussion of Experts and Expertise in Heritage Studies." International Journal of Heritage Studies 25, no. 8: 825-836. https://doi.org/10.1080/13527258.2018.1552613

Ibenholt, Karin, Rasmus Reinvang, Hanne Tofedahl and Phillip Swanson. 2013. Evaluation of Nordic World Heritage Foundation (2008-2013). Rapport 2013/40. Oslo: Vista Analyse.

James, Luke C. and Tim Winter. 2015. "Expertise and the Making of World Heritage Policy." International Journal of Cultural Policy 23, no. 1: 36-51. https://doi.org/10.1080/10286632.2015.1035267

Jensen, Mette B. 2009. "Kulturarven og myten om den historiske identitet. En diskursanalyse af arkæologiens rolle i det senmoderne samfunn." PhD diss, Aarhus Universitet.

Johansson, Marit. 2015. "Life in a World Heritage City. A Case Study of Discussions and Contested Values in Angro do Heroísmo, the Azores." PhD diss, Linköping University.

Jokilehto, Jukka. 2011. "World Heritage: Observations on Decisions Related to Cultural Heritage." Journal of Cultural Heritage Management and Sustainable Development 1, no. 1: 61-74. https://doi.org/10.1108/20441261111129942

Jones, Siân. 2017. "Wrestling with the Social Value of Heritage: Problems, Dilemmas and Opportunities." Journal of Community Archaeology \& Heritage 4, no. 1: 21-37. https://doi.org/10.1080/20518196.2016.1193996 
Klimaszewski, Cheryl, Gail. E. Bader, and James M. Nyce. 2012. "Studying Up (and Down) the Cultural Heritage Preservation Agenda: Observations from Romania." European Journal of Cultural Studies 15, no. 4: 479-495. https://doi.org/10.1177\%2F1367549412455495

Källén, Anna. 2014. "The Invisible Archaeologist: Letters from the UNESCO Secretariat 1946-1947." Journal of Social Archaeology 14, no. 3: 383-405. https://doi.org/10.1177\%2F1469605314545580

Kuus, Merje. 2014. “Transnational Bureaucracies: How Do We Know What They Know?" Progress in Human Geography 39, no. 4: 432-448. https://doi.org/10.1177\%2F0309132514535285

Kohl, Philip L. and Clare Fawcett. eds. 1995. Nationalism, politics, and the practice of archaeology. Cambridge: Cambridge University Press.

Kohl, Philip L. 1998. Nationalism and archaeology: on the constructions of nations and the reconstructions of the remote past. Annual Review of Anthropology 27, no. 1: 223-246.

Labadi, Sophia. 2013. UNESCO, Cultural Heritage, and Outstanding Universal Value. Value-based Analyses of the World Heritage and Intangible Cultural Heritage Conventions. Lanham: Altamira Press.

Labadi, Sophia. 2007. Representations of the nation and cultural diversity in discourses on World Heritage. Journal of Social Archaeology, 7, no. 2: 147-170. https://doi.org/10.1177/1469605307077466

LGM 2019. "Guidelines. About the Relationship between Political Leadership and the Civil Service. Seven Duties for the Civil Service." Royal Norwegian Ministry of Local Government and Modernisation.

Lucas, Gavin. 2015. "The Mobility of Theory." Current Swedish Archaeology 23: 13-32.

Luke, Christina. 2016. "The 40th World Heritage session in Istanbul, Turkey: A reflection on the legacies of heritage policy and missed Mega-Heritage." Journal of Field Archaeology 41, no. 6: 641-644, DOI: 10.1080/00934690.2016.1242708

Luke, Christina. 2018. "Heritage Interests: Americanism, Europeanism and Neo-Ottomanism." Journal of Social Archaeology 18, no. 2: 234-257. https://doi.org/10.1177\%2F1469605318771828

Luke, Christina, and Morag M. Kersel. 2013. U.S. Cultural Diplomacy and Archaeology. Soft power, hard heritage. New York/London: Routledge.

Lähdesmäki, Tuuli. 2014. "The EU's Explicit and Implicit Heritage Politics." European Societies, 16, no. 3: 401-421, DOI: 10.1080/14616696.2014.894547

Meskell, Lynn. 2012a. "The rush to inscribe: Reflections on the 35th Session of the World Heritage Committee, UNESCO Paris, 2011.” Journal of Field Archaeology 37, no. 2: 145-151. https://doi.org/10.1179/0093469012Z.00000000014

Meskell, Lynn. 2012b. "Archaeological Ethnography: Materiality, Heritage and Hybrid Methodologies." In Archaeology and Anthropology. Past, Present and Future, edited by David Shankland, 133-144. London/New York: Berg.

Meskell, Lynn. 2014. "States of Conservation: Protection, Politics, and Pacting within UNESCO's World Heritage Committee." Anthropological Quarterly 87, no. 1: 217-243. https://doi.org/10.1353/anq.2014.0009

Meskell, Lynn. 2015. "Transacting UNESCO World Heritage: Gifts and Exchanges on a Global Stage." Social Anthropology 23, no. 1: 3-21. https://doi.org/10.1111/1469-8676.12100

Meskell, Lynn. 2016. "World Heritage and WikiLeaks." Current Anthropology 57, no. 1: 72-95. https://doi.org/10.1086/684643

Meskell, Lynn. 2018. A Future in Ruins. UNESCO, World Heritage, and the Dream of Peace. Oxford: Oxford University Press.

Milek, Karen. 2018. "Transdisciplinary Archaeology and the Future of Archaeological Practice: Citizen Science, Portable Science, Ethical Science.” Norwegian Archaeological Review, 51, no. 1-2: 36-47. DOI: 10.1080/00293652.2018.1552312

Mortensen, Lena and Julie Hollowell eds. 2009. Ethnographies and archaeologies: iterations of the past. Gainesville: University Press of Florida.

Mosse, David. 2006. "Anti-social anthropology? Objectivity, Objection, and the Ethnography of Public policy and Professional Communities." Journal of the Royal Anthropological Institute 12: 935-956. 
Mosse, David. 2011. "Politics and Ethics: Ethnographies of Expert Knowledge and Professional Identities." In Policy worlds: Anthropology and the analysis of contemporary power, edited by Cris Shore, Susan Wright and Davide Pero, 50-67. Oxford: Berghahn.

Nader, Laura. 1972. "Up the Anthropologist - Perspectives Gained from Studying Up." In Reinventing Anthropology, edited by D. Hymes, 284-311. New York: Pantheon Books.

Nielsen, Bjarke. 2011. "UNESCO and the 'Right' Kind of Culture: Bureaucratic Production and Articulation." Critique of anthropology 31, no. 4: 273-292. https://doi.org/10.1177\%2F0308275X11420113

Niklasson, Elisabeth. 2013. "Archaeology as European Added Value.” In, Appropriate narratives: archaeologists, publics and stories, edited by Elisabeth Niklasson and Thomas Meier, 49-86. Budapest: Archaeolingua.

Niklasson, Elisabeth. 2016. "Funding matters: Archaeology and the Political Economy of the Past in the EU." PhD diss, Stockholm University.

Niklasson, Elisabeth. 2017. "The Janus-face of European Heritage: Revising the Rhetoric of Europemaking in EU Cultural Policies.” Journal of Social Archaeology 17, no. 2: 138-162. https://journals.sagepub.com/doi/abs/10.1177/1469605317712122

Niklasson, Elisabeth. 2019. "Borders of Belonging in the European Heritage Label." In Heritage and Borders, edited by Anna Källén. Stockholm: Royal Swedish Academy of Letters, History and Antiquities. In press.

Niklasson, Elisabeth and Herdis Hølleland. 2018. "The Scandinavian Far-right and the New Politicisation of Heritage." Journal of Social Archaeology 18, no. 2: 121-148. https://doi.org/10.1177\%2F1469605318757340

Oxford English Dictionary 2019. "Gatekeeping.” Accessed January 29, 2019. https://en.oxforddictionaries.com/definition/gatekeeping.

Plets, Gertjan. 2016. "Heritage Bureaucracies and the Modern Nation State. Towards an Ethnography of Archaeological Systems of Government." Archaeological Dialogues 23, no. 2: 193-213. https://doi.org/10.1017/S1380203816000222

Pyburn, Anne K. 2009. "Practising Archaeology - As if it Really Matters." Public Archaeology 8, no. 2-3: 161-175. DOI: 10.1179/175355309X457204

Rao, Kishore. 2010. "A New Paradigm for the Identification, Nomination and Inscription of Properties on the World Heritage List." International Journal of Heritage Studies 16, no. 3: 161-172. https://doi.org/10.1080/13527251003620594

Richards, David. 1996. "Elite Interviewing: Approaches and pPtfalls." Politics 16, no. 3: 199-204. https://doi.org/10.1111/j.1467-9256.1996.tb00039.x

Richardson, Lorna-Jane. 2017. 'I'll Give You 'Punk Archaeology', Sunshine.” World Archaeology 49, no. 3: 306-317. https://doi.org/10.1080/00438243.2017.1333036

Ronström, Owe. 2009. Kulturarvspolitik. Visby: från sliten småstad till medeltidsikon. Stockholm: Carlssons.

Samuels, Kathryn L. 2016. Transnational turns for archaeological heritage: From conservation to development, governments to governance, Journal of Field Archaeology, 41, no. 3: 355367. https://doi.org/10.1080/00934690.2016.1174031

Samuels, Kathryn L. 2019. "Heritage Development: Culture and Heritage at the World Bank." In The cultural turn in international aid: impacts and challenges for heritage and the creative industries, edited by Sophia Labadi, 55-72. London: Routledge.

Schmidt, Thomas M. 2009. "Global Cultural Governance. Decision-making Concerning World Heritage between Politics and Science." Erkunde 63, no. 2: 103-121.

Schofield, John., ed. 2014. Who needs heritage experts? Counter-mapping cultural heritage. London: Routledge.

Shore, Cris. 2000. Building Europe: The Cultural Politics of European Integration. London: Routledge.

Silberman, Neil. 2014. "Changing visions of heritage value: what role should the experts play?" Ethnologies 36, no. 1-2: 433-445.

Smith, Laurajane. 2004. Archaeological Theory and the Politics of Cultural Heritage. London: Routledge.

Smith, Laurajane. 2006. Uses of Heritage. London: Routledge. 
Smith, Laurajane, and Emma Waterton. 2009. Heritage, Communities and Archaeology. London: Bloomsbury Academic.

Smith, Laurajane, and Emma Waterton 2010. "The Recognition and Misrecognition of Community Heritage." International Journal of Heritage Studies 16, no. 1-2: 4-15. https://doi.org/10.1080/13527250903441671

Smith, Laurajane, Paul Schackel, and Gary Cambell. 2011. Heritage, Labour and the Working Classes. London: Routledge.

Souleles, Daniel. 2018. "How to Study People Who Do Not Want to be Studied: Practical Reflections on Studying Up." Political and Legal Anthropology Review 41, no. S1: 51-68.

Storeng, Katerini and Jennifer Palmer. 2019. When ethics and politics collide in donor-funded global health research. The Lancet Online. DOI: http://dx.doi.org/10.1016/S0140-6736(19)30429-5

Stutz, Liv Nilsson 2018. "A Future for Archaeology: In Defense of an Intellectually Engaged, Collaborative and Confident Archaeology." Norwegian Archaeological Review 51, no. 1-2: 48-56. https://doi.org/10.1080/00293652.2018.1544168

Sveriges Radio 2015. "Så ska arkeologerna rädda EU [This is How Archaeologists Try to Save the EU]." Vetenskapsradion Historia, 05 March 2015. Accessed March 6, 2019. https://sverigesradio.se/sida/avsnitt/511236?programid=407.

SVT 2016. "Europeisk identitet - vad är det? [European Identity - What is it?]." Vetenskapsradion Historia, 20 April 2016. Accessed March 6, 2019. https://www.svt.se/kultur/europeiskidentitet.

Thomas, Deborah A. 2018. "Decolonizing Disciplines." American Anthropologist 120, no. 3: 393-97. Titchen, Sarah M. 1995. "On the Construction of Outstanding Universal Value. UNESCO's World Heritage Convention (Convention Concerning the Protection of the World Cultural and Natural Heritage, 1972) and the Identification and Assessment of Cultural Places for Inclusion in the World Heritage List." PhD diss, Australian National University.

Tornatore, Jean-Louis. 2012. "Anthropology's Payback: 'The Gastronomic Meal of the French." The Ethnographic Elements of a Heritage Distinction. In Heritage Regimes and the State, edited by Regina F. Bendix, Aditya Eggert and Arnika Peselmann, 341-365. Göttingen Studies in Cultural Property 6. Universitätsverlag Göttingen.

Trigger, Bruce G. 1984. "Alternative Archaeologies: Nationalist, Colonialist, Imperialist”. Man 19, no. 3: 355-370.

Trigger, Bruce G. 1989. A history of archaeological thought. Cambridge: Cambridge University Press.

Trondal, Jarle, Martin Marcussen, Torbjörn Larsson and Frode Veggeland. 2010. Unpacking international organisations. The dynamics of compound bureaucracies. Manchester: Manchester University Press.

Turtinen, Jan. 2006. "Världsarvets villkor. Intressen, förhandlingar och bruk i internationell politik." $\mathrm{PhD}$ diss, Stockholm University.

Vos, Claske. 2011. "Negotiating Serbia's Europeanness: On the Formation and Appropriation of European Heritage Policy in Serbia." History and Anthropology 22, no. 2: 221-242. https://doi.org/10.1080/02757206.2011.558584

Verlot, Marc. 2001. "Are Politicians Human? Problems and Challenges of Institutional Anthropology." Social Anthropology 9, no. 3: 345-353. https://doi.org/10.1111/j.14698676.2001.tb00162.x

Weiss, T. G. 2009. What's Wrong with the United Nations and How to Fix It. Cambridge: Polity.

Zarger, Rebecca K., and Thomas J. Pluckhahn. 2013. "Assessing methodologies in archaeological ethnography: a case for incorporating ethnographic training in graduate archaeology curricula." Public Archaeology 12, no. 1: 48-63. 